\title{
Modelling of Leaching Effect on Some Properties of Salt Affected Calcareous Soils at Maryout Region, West of Delta
}

\author{
Ahmed M. A. Harga and Mohamed E. A. Khalifa 1
}

\begin{abstract}
Due to the importance of Maryout region for its potential rehabitation and calcareous soil reclamation, three sites pertaining wide range of soil salinity from 250 to $2.5 \mathrm{dS} / \mathrm{m}$ were selected to model salts leaching. In order to obtain a sound basis for field reclamation under different conditions, a leaching experimental model was undertaken laboratorial using three soil columns simulating these three sites which varying mainly in salinity levels to assess the effect of several factors on the effectiveness of salt removal. The experiment was performed twice with and without removal of $\mathrm{CaCO}_{3}$. There are four problems were investigated based on the experiment; the evolution of leachates salinity with time, monitoring the changes of ion loses and changes of chemical composition of drained leachates, the effect of leaching process on particle size distribution and fine particles migration at each salinity level, and the probabilities of Calcic horizon formation. Also the study emphasized on the influence of carbonate removal on leachates salinity.
\end{abstract}

Results showed that the counts of required leachates for salinity minimizing were 20,15 and 12 with total leachates volume 1552, 1055 and $732 \mathrm{~cm}^{3}$ during leaching periods (hr:m) 10:48, 7:41 and 5:59, respectively. Soil texture was clay loam (CL) at the first location, clay $(C)$ at the second site except for the middle layer which has sandy clay loam (SCL) texture, while at the third location soil texture was clay loam (CL) at surface and clay (C) at subsurface. Results of particle size distribution indicated that lime removal in general increased percentage of fine particles in contrast in course ones. After leaching of free lime columns fine particles percentages were decreased at surface horizons of extremely and highly saline soils more than slightly saline column. Clay particles immigrated after leaching downward which increase their content at last horizons by $\mathbf{2 2 . 7}$ and $\mathbf{7 . 1 \%}$ for first and second columns, respectively.

The electrical conductivity values of the second drained leachate fractions were reduced significantly by about $\mathbf{7 7 . 8 \%}, 57.1 \%$ and $15.6 \%$, respectively. After the experiment was turned off the stable salinity level for whole leachates were $0.74,0.44$ and $0.16 \mathrm{dSm}^{-1}$, respectively. Thus, leaching succeeded in removing about 99.7 \%, 98.2 \% and 93.6\% from the total salt content. Results indicated that the ionic loss was orderly as $\mathrm{Na}^{+}, \mathrm{Cl}^{-}$, $\mathrm{Ca}^{++}, \mathrm{Mg}^{++}$then $\mathrm{K}^{+}$in descending order in whole drained leachates, where removed cations essentially were in chloride or sulfate forms. Estimated rates of $\mathrm{CaCO}_{3}$ deposition for the studied soils were 19.9, 16.4 and 9.5 $\mathrm{g} / \mathrm{m}^{3} /$ year, respectively. Dominant lime horizons will receive $0.76,0.64$ and $0.37 \%$ of carbonate after 500 years at the studied sites, respectively, which indicate unsuitable conditions for Calcic horizon formation during that period.

The model tried to simulate field conditions associated to leaching of salty calcareous soils, but nutrients levels have to be carefully monitored to sustain healthy plant growth, and it is usually not advisable to leach if the resulting soil will be sodic or alkali, where such soils should receive amendments before being leached.

\section{INTRODUCTION}

The world's current population arrownding 6 billion people anticipated to reach 10 billion by 2050 . There will be a corresponding increase in the demands placed upon the land resources necessary for maintaining food production (Maas, 1994). Yet, general trends refering to a considrable decreasing of arable land, in which greater demands on utilizing marginal resources were placed.

It is estimated that more than 6 million hectares of land are lost each year due to drainage and salinization problems (Jarvis et. al., 1991). Soil salinity is natural component of desert agricultural systems and has plagued many attempts at developing and maintaining crop production systems in arid regions (Poulovassilis et. al., 2007). Clearly, the best strategies and techniques for optimum management of salt-affected soils became important topic for agricultural development particularly in arid and semi arid lands (Maas, 1994).

The first step in developing appropriate management schemes for dealing with saline soil conditions involves proper identification (Andrew and Gaffney, 2000). On the other hand, the spatial variability of soil properties in general caused problems for deterministic models using rate parameters. Therefore, a number of conceptual models for solute leaching in soil were performed (Addiscott and Wagene, 2007). Few data sets are available for testing a range of models and few models have been tested on a range of soil types, and very few models have much demonstrable ability to simulate transient field leaching conditions (Hall, 1993).

During the recent few years a number of complex simulation physical models describing the dynamics of the soil-water system have been developed (Feddes et. al., 1988). Soil Water Actual Transpiration Rate (SWATR) model was designed by Feddles et. al., (1978) to describe water transition flow in a

${ }^{1}$ Pedology Dept, Desert water resources and land,

Desert Research Center, Egypt

Received June 23, 2011, Accepted June 29, 2011 
heterogeneous soil. Belmans et. al., (1983) developed a one dimensional model to simulate water and solute movement through the profile. Dam Van et. al., (1990) modeled the solute and sediment transport under irrigation. L. Cai, et. al., (2000) carried out a modeling study to evaluate water and salt movement within a transitional B horizon of saline soil. Scotter et. al., (1991) designed two models to simulate leaching process of non-reactive solute to a mole drain. Addiscott and Whitmore (1991) carried out an experiment to model the solute leaching in soils of differing permeabilities. Vinten and Redman (1993) studied the non-interactive solute leaching in a clay-loam arable soil using an experimental model, then they validate obtained results according to field conditions.

One of the most important local trials of salt leaching was carried by Samir A. M. et. al., (1977) where the dynamic process of leaching was investigated at wadi El-Natrun and dairot by physical simulation using soil columns.

Calcium carbonate precipitates in soil as a result of downward movement of $\mathrm{Ca}$ with percolated leaching water. Therefore, many models have been developed to simulate lime movement and accumulation in soils under leaching conditions (Rabenhorst et al., 1991). Zahow (1988) designed a simulation model to predict salt dynamics in calcareous soil and estimated carbonate accumulation and calcic horizon formation.

Rabenhorst et al. (1991) identified the state factors that influence the formation of soil calcic horizon as; type of parent material, percentage of $\mathrm{CaCO}_{3}$ with corresponding depths, leached water quantity that entering the soil, and water holding capacity that affecting $\mathrm{CO}_{2}$ concentration which control $\mathrm{pH}$ lime solubility as seen in eq. (1).

$\mathrm{CaCO}_{3}+\mathrm{CO}_{2}+\mathrm{H}_{2} \mathrm{O} \rightleftarrows \mathrm{Ca}^{++}+2 \mathrm{HCO}_{3}^{-}$

Where, $\mathrm{CO}_{2}$ pressure decreased with soil depth which affect the reaction tends by mass action to shift toward the left side of lime precipitation.

This study aimed at monitoring the changes in some properties of salt affected calcareous soils under leaching process. An expermintal model was carried out using three soil columns having different salinity levels to simulate salt leaching as a soil reclamation technique. Particle size distribution, salinity downwarding and chemical composition of drained leachates were the main analyzed soil properties. The study also investigated the infeluence of lime removal on salt leaching effectivness as well as the salinity level on downwarding rate. Further, the study illustrates the lime downwarding/stoppage estimation under leaching conditions with associated probabilities of calcic horizon formation.

Maryout region which located at the dominant coastal calcareous environment was selected as studied area due to the significance variation in salinity as affected by Maryout lake. Lots of current agrarian land uses were affected by salinity rising in the studied area with different influencing degrees.

\section{STUDY AREA}

\section{1- Location:}

The study area was located at Maryout region in the western north coastal zone of Egypt. Three sites were selected in the area at the following coordination; (1)

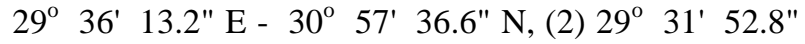
E - 30 56' 00.8" N and (3) $29^{\circ} 29^{\prime} 49.8^{\prime \prime} \mathrm{E}-30^{\circ} 54^{\prime}$ 29.0" N (Map 1).

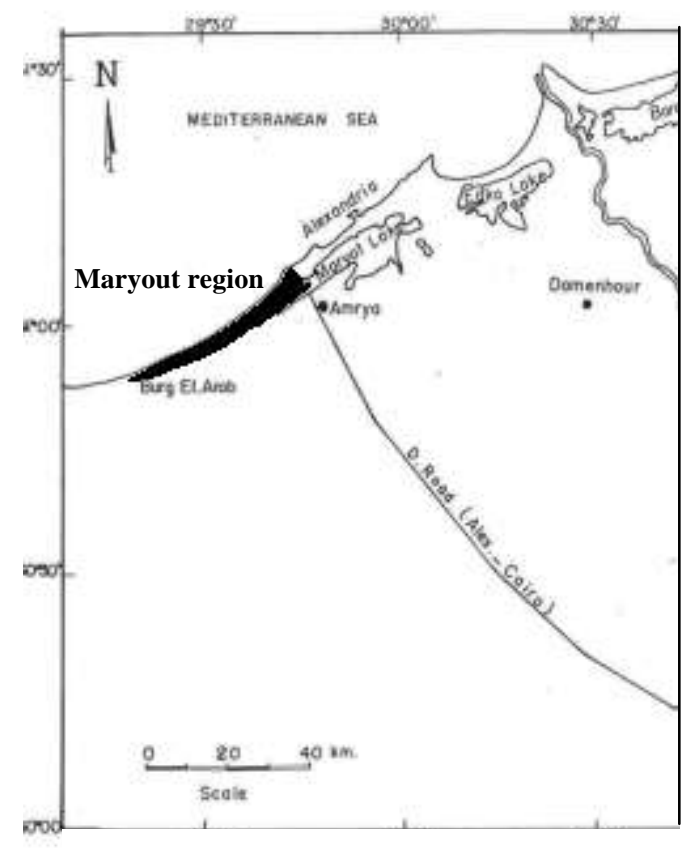

Map 1. Location of the studied area

\section{2-Geology:}

Said (1962) reported that generally the area under consideration is occupied by sedimentary rocks essentially belonging to the Quaternary deposits found in the form of alluvial terraces deposited in the depression, and in the form of a thin mantle of transported soils occurring on the top of the surrounding plateau. The fossiliferous indurate limestone which represented the Miocene formation forms the main strata, which is overlain by the calcareous Pliocene and Pleistocene formations, in which the marine-lacustrine sediments (Shata, 1971). 


\section{3- Geomorphology:}

Geomorphologically, Maryout region described as an intervening lateral depression with absence of elongated ridges this is obviously due to the effect of the westerly and northerly marine currents, as well as the presence of marine deposits in the depression valley (Hammad 1972). Surfaces of the studied locations is almost flat and having elevations of 7, 9, $31 \mathrm{~m} \mathrm{A.S.L.,}$ respectively.

\section{4- Vegetations and surface cover:}

Natural saline vegetations scattered and occupying most of the area under consideration such as Attriplex species. The area was partially cultivated with barely and some vegetables as found at the third location. Varisized salt crystals and nodules were embedded at the first site soil surface which indicates extremely saline condition. Isolated many shallow bonds scattered over some areas at the third location. Land surfaces of the studied locations were covered with shells and their fragments.

\section{MATERIALS AND METHODS}

\section{1- Field work:}

Three different calcareous soils at Maryout region were chosen based on their variation of initial salinity levels; extremely saline, saline, and non saline. Representative soil profiles were dug to a depth of 150 $\mathrm{cm}$, carefully described morphologically according to FAO (1998). Soil samples were collected from each layer and subjected to laboratory analyses.

\section{2- Laboratory analysis:}

Saturation percentage (S.P\%) was determined according to Page et al.(1982), Chemical analyses of saturated extract for $\mathrm{pH}, \mathrm{EC}$, and soluble cations and anions were measured according to Page et al.(1982), Particle size distribution, with and without removal of $\mathrm{CaCO}_{3}$, was determined as outlined by James (2007), Total $\mathrm{CaCO}_{3}(\%)$ was determined using calcimeter apparatus according to Black (1965), and Real particle density was identified using Richards (1954).

\section{3- Experiment design:}

For each soil profile, successive samples to a depth of $80 \mathrm{~cm}$ were packed in approximately $11 \mathrm{~cm}$ diameter (3.64") separate cylindrical transparent glass columns.
During packing, thickness of each soil layer in a column was made similar to that corresponding in the field. For all soil columns, the apparent densities of all layers were almost constant, so that variations in leaching efficiency among different soil layers could be eliminated.

Continuous leaching technique was applied in the current investigation, where a constant head of distilled water with $12 \mathrm{~cm}$ depth maintained to overlay the upper end of each column throughout the experiment. As soon as water was applied to the columns, the soils became saturated after a while. The saturated hydraulic conductivity was calculated for each soil column as indication of water movement with time inside the soil. An effluent collector was placed under the lower end of each column to collect separate periodic fractions of the percolated solutions (leachates), simultaneously with continuous detection of salinity levels in all collected leachates.

Leaching process was stopped when the electric conductivity of drained water fractions become almost constant. The total numbers of collected leachates were counted for the first, second, and third profiles. Finally, according to the thickness of each layer the columns were divided into several sections in which the particle size distribution analysis was performed again. Table (1) describes the entire configuration of modeled experiment.

\section{4- Lime content estimation:}

Based on the performed experiment, the study conducted a simulation of $\mathrm{CaCO}_{3}$ movement under define water quantity using computerized modeling of the regional model for soil $\mathrm{CaCO}_{3}$ deposition (CALDEP) software (Marion et. al., 1985). That package was developed as soil carbonate deposition model which used successfully for long term simulation. The required input data were measured and presented in three input files; first input file contained chemical analysis of irrigation water and data of evapotranspiration, second file deals with initial soil chemical parameters like salts concentration and lime content, while the third input file concerned with soil physical properties as texture and hydraulic conductivity.

\section{Table 1. Experimental design parameters and configuration}

\begin{tabular}{|c|c|c|c|c|c|c|c|c|}
\hline & \multicolumn{3}{|c|}{ Column 1} & \multicolumn{3}{|c|}{ Column 2} & \multicolumn{2}{|c|}{ Column 3} \\
\hline W. Head depth, cm & \multicolumn{3}{|c|}{12} & \multicolumn{3}{|c|}{12} & \multicolumn{2}{|c|}{12} \\
\hline Length, cm & \multicolumn{3}{|c|}{80} & \multicolumn{3}{|c|}{80} & \multicolumn{2}{|c|}{80} \\
\hline Diameter, cm & \multicolumn{3}{|c|}{$\approx 11(3.64 ")$} & \multicolumn{3}{|c|}{$\approx 11(3.64 ")$} & \multicolumn{2}{|c|}{$\approx 11(3.64 ")$} \\
\hline Layers Depth, cm & $0-12$ & $12-30$ & $30-80$ & $0-10$ & $10-30$ & $30-80$ & $0-20$ & $20-80$ \\
\hline Volume, $\mathrm{cm}^{3}$ & 124.8 & 187.2 & 520.1 & 108.1 & 216.1 & 504.2 & 208.0 & 624.1 \\
\hline Mass, gm & 159.8 & 249.8 & 666.3 & 147.2 & 294.3 & 736.3 & 283.3 & 349.9 \\
\hline
\end{tabular}


The carbonate content was estimated for the three studied soils over time along 500 years using the finite difference solution according to equation no. (2).

$$
\frac{\partial C \theta}{\partial t}=\frac{\partial}{\partial z}\left[D(\theta, q) \frac{\partial C}{\partial z}\right]-\frac{\partial}{\partial z}(q C)
$$

Where: $\mathrm{C}$ is lime concentration (\%), $\mathrm{q}$ is water flux $(\mathrm{cm} / \mathrm{hr}), \Theta$ is water content $\left(\mathrm{cm}^{3} / \mathrm{cm}^{3}\right), \mathrm{z}$ is depth and $\mathrm{D}$ $(\Theta, q)$ is diffusion constant. A linear relationship between estimated lime content with time was undertaken, where regression coefficients were calculated for each examined soil.

\section{RESULTS AND DISCUSSION}

Results indicated that studied soils have medium soil hydraulic conductivity values which were $2.89,2.95$ and $3.11 \mathrm{~cm} / \mathrm{hr}$, respectively. The total counts of collected leachates were equal 20,15, and 12 for the first, second, and third profiles, respectively table (2). Extremely saline column consumed the much higher water quantity and time for leaching.

\section{1- Routine characterization:}

The analytical data of soils as seen in table (3) emphasized on that variation between selected sites, which was mainly due to the differences in salinity levels between these three profiles. The total salinity varied between $250 \mathrm{dS} / \mathrm{m}$ in the first profile which represents the extremely saline soils, one tenth $(25$ $\mathrm{dS} / \mathrm{m}$ ) in the second which represents the highly saline soils, and one tenth $(2.5 \mathrm{dS} / \mathrm{m})$ in the third one which represent the slightly saline soils. A tendency of salt decrease with depth is quite common. Results of salts composition show that the predominant anion is chloride, while the predominant cations are sodium and magnesium in the first and second profiles, while calcium and/or sodium in the third one (table 3). As usual at coastal sites, lime content $\left(\mathrm{CaCO}_{3} \%\right)$ is high with increase tendency towards depth.

Table (4) summarized the results of performed mechanical analysis, where soil texture ranged between sandy clay loam and clay. Soil texture of the extremely saline layers was similar as clay loam which may be indicate a steady leaching flow. Other soils have heavier texture, where highly saline soil has clay texture class at both of surface and bottom layers while slightly saline one has a clay texture at the bottom.

\section{2- Particles size distribution (PSD)}

2.1- PSD of extremely saline soils: Leaching of the first extremely saline soil column led to down immigration of some particles from the first horizon

Table 2. Routine soil physical properties of investigated soils

\begin{tabular}{|c|c|c|c|c|c|c|c|c|}
\hline \multirow[b]{2}{*}{ S.P (\%) } & \multicolumn{3}{|c|}{ Column 1} & \multicolumn{3}{|c|}{ Column 2} & \multicolumn{2}{|c|}{ Column 3} \\
\hline & 32.8 & 35.2 & 36.5 & 34.0 & 32.6 & 31.8 & 33.5 & 35.9 \\
\hline Bulk dens. $\left(\mathrm{g} / \mathrm{cm}^{3}\right)$ & 1.28 & 1.33 & 1.28 & 1.36 & 1.36 & 1.36 & 1.36 & 1.36 \\
\hline Porosity $(\%)$ & 45.0 & 51.6 & 49.8 & 46.5 & 47.9 & 45.2 & 48.1 & 48.5 \\
\hline Hyd. Conduct. $(\mathrm{cm} / \mathrm{hr})$ & \multicolumn{3}{|c|}{2.89} & \multicolumn{3}{|c|}{2.95} & \multicolumn{2}{|c|}{3.11} \\
\hline Leachates count & \multicolumn{3}{|c|}{20} & \multicolumn{3}{|c|}{15} & \multicolumn{2}{|c|}{12} \\
\hline Leachates vol. $\left(\mathrm{cm}^{3}\right)$ & \multicolumn{3}{|c|}{1552} & \multicolumn{3}{|c|}{1055} & \multicolumn{2}{|c|}{732} \\
\hline Time of leaching (h:m:s) & \multicolumn{3}{|c|}{$10: 48$} & \multicolumn{3}{|c|}{$07: 41$} & \multicolumn{2}{|c|}{$05: 59$} \\
\hline
\end{tabular}

Table 3. Soil analysis of the studied profiles before salts leaching

\begin{tabular}{|c|c|c|c|c|c|c|c|c|c|}
\hline \multirow{4}{*}{\multicolumn{2}{|c|}{$\begin{array}{l}\text { Salinity class } \\
\text { Horizon depth, cm }\end{array}$}} & \multicolumn{3}{|c|}{ Site 1} & \multicolumn{3}{|c|}{ Site 2} & \multirow{2}{*}{\multicolumn{2}{|c|}{$\begin{array}{c}\text { Site } 3 \\
\text { Slightly saline }\end{array}$}} \\
\hline & & \multicolumn{3}{|c|}{ Extremely saline } & \multicolumn{3}{|c|}{ Highly saline } & & \\
\hline & & $0-12$ & $12-30$ & $30-80$ & $0-10$ & $10-30$ & $30-80$ & $0-20$ & $20-80$ \\
\hline & & 22.8 & 23.9 & 26.8 & 27.9 & 25.9 & 32.4 & 36.7 & 40.0 \\
\hline pH & & 7.9 & 7.8 & 7.8 & 7.6 & 7.4 & 7.2 & 7.8 & 7.8 \\
\hline $\mathrm{EC}, \mathrm{dS} / \mathrm{m}$ & & 250.0 & 110.0 & 80.0 & 25.0 & 2.4 & 20.0 & 2.5 & 2.2 \\
\hline \multirow{4}{*}{$\begin{array}{c}\text { Soluble } \\
\text { Cations, } \\
\text { meq/100g }\end{array}$} & $\mathrm{Ca}^{++}$ & 11.29 & 4.69 & 5.8 & 1.21 & 0.36 & 2.40 & 0.27 & 0.58 \\
\hline & $\mathrm{Mg}^{++}$ & 18.35 & 6.50 & 5.80 & 1.71 & 0.28 & 0.65 & 0.04 & 0.08 \\
\hline & $\mathrm{Na}^{+}$ & 40.16 & 27.88 & 19.34 & 10.21 & 0.32 & 1.96 & 0.54 & 0.40 \\
\hline & $\mathbf{K}^{+}$ & 0.40 & 0.19 & 0.29 & 0.21 & 0.03 & 0.05 & Tr. & Tr. \\
\hline \multirow{4}{*}{$\begin{array}{c}\text { Soluble } \\
\text { Anions } \\
\text { meq/100g }\end{array}$} & $\mathrm{CO}_{3}{ }^{--}$ & Tr. & Tr. & Tr. & Tr. & Tr. & Tr. & Tr. & Tr. \\
\hline & $\mathrm{HCO}_{3}{ }^{-}$ & 0.10 & 0.05 & 0.05 & 0.05 & 0.05 & 0.08 & 0.10 & 0.15 \\
\hline & $\mathrm{Cl}^{-}$ & 69.7 & 29.5 & 24.2 & 6.60 & 0.98 & 4.52 & 0.78 & 0.51 \\
\hline & $\mathrm{SO}_{4}{ }^{--}$ & 0.016 & 0.026 & 0.018 & 0.085 & 0.008 & 0.006 & 0.06 & 0.21 \\
\hline
\end{tabular}


Table 4. Mechanical analysis of the investigated soils before the experiment

\begin{tabular}{lcccccccc}
\hline & \multicolumn{3}{c}{ Site 1 } & \multicolumn{3}{c}{ Site 2} & \multicolumn{2}{c}{ Site 3} \\
\hline Horizon depth, $\mathbf{c m}$ & $0-12$ & $12-30$ & $30-80$ & $0-10$ & $10-30$ & $30-80$ & $0-20$ & $20-80$ \\
\hline C. Sand \% $(\mathbf{2 0 0 - 2 0 0 0} \boldsymbol{\mu}) *$ & 1.21 & 0.79 & 0.95 & 2.26 & 4.43 & 0.49 & 3.00 & 2.42 \\
\hline F. Sand \% $\mathbf{( 2 0 - 2 0 0} \boldsymbol{\mu})$ & 36.15 & 37.07 & 37.76 & 29.52 & 44.80 & 20.65 & 42.01 & 30.65 \\
\hline Silt \% $\quad(\mathbf{2 - 2 0} \boldsymbol{\mu})$ & 23.34 & 12.35 & 29.86 & 25.68 & 23.63 & 28.40 & 18.82 & 25.51 \\
\hline C. Clay \% $(\mathbf{1 - 2} \boldsymbol{\mu})$ & 7.48 & 7.55 & 5.67 & 10.50 & 4.43 & 10.55 & 8.24 & 11.63 \\
\hline F. Clay \% $(<\mathbf{1} \boldsymbol{\mu})$ & 31.82 & 27.24 & 25.76 & 32.04 & 22.71 & 39.91 & 27.93 & 29.79 \\
\hline Soil Texture class** & CL & CL & CL & C & SCL & C & CL & C \\
\hline
\end{tabular}

* Diameters according to the International Soil Science Society (ISSS), $\mathrm{C}=\mathrm{Coarse}, \mathrm{F}=$ Fine

** $\mathrm{CL}=$ Clay loam $\quad \mathrm{C}=$ Clay $\quad \mathrm{SCL}=$ Sandy clay loam

$(0-12 \mathrm{~cm})$ where fine grains percentage (less than $1,1-2$, $2-5 \mu)$ was decreased after leaching. As the grain diameter increase as the transportation decreased. On the other hand, percentage of course particles $(5-10,10-$ $20,20-200 \mu)$ increased at the upper horizon. In contrast, the lower horizon $(30-80 \mathrm{~cm})$ received transported fine particles which led to successive decreasing of course grain percentage with diameter as seen in figure (1A) which illustrates the differences between particle size distributions before and after leaching.

Removal of lime from the first column as a cementing agent between particles maximize the content of fine grains at the upper layer, while course grains content $(20-200 \mu)$ almost remained as it is after lime removal. While quantity of course particles $(20-200 \mu)$ at the second $(12-30 \mathrm{~cm})$ and the third $(30-80 \mathrm{~cm})$ layers were affected negatively with lime removal.

Lime removal from first soil column maximize the leaching effectiveness in particles removal from the upper horizon, where fine free lime particles content obviously decreased after leaching, than its percentage with carbonate. On the other hand, free lime course soil grains at the first and second horizons were increased significantly after leaching more that before lime removal as shown in figure (1A) which illustrates the effect of leaching at the extremely saline soils with and without lime removal. The effect of leaching was maximized again in increasing course grains content at second layer $(12-30 \mathrm{~cm})$, while at third layer $(30-80 \mathrm{~cm})$ course particles obviously decreased after leaching due to receiving significant amount of immigrated fine particles from upper horizons (Fig. 1a). In general, sediments transport were very clear at the extremely saline soils due to the effect of leaching in dissolving salt formations and concretions which increase particles mobility, that led to noticeable variability in particle size distribution between horizons.

2.2- PSD of highly saline soils: In general, the fine particles content (less than $1 \mu$ ) was lower than course particles content (20-200 $\mu)$ at the second horizon (10$30 \mathrm{~cm})$ in contrast with lower layer $(30-80 \mathrm{~cm})$ as showed in figure (1B). The experiment indicated that leaching at highly saline soils had no obvious effect as showed in the extremely saline soil column. Limited quantity of fine particles (less than $1 \mu$ ) immigrated from the upper layer $(0-10 \mathrm{~cm})$ to be precipitated at the last layer $(30-80 \mathrm{~cm})$. Unexpected effects of leaching at the upper layer on course particles content $(20-200 \mu)$ which were nearly not influenced due to relative increments occur in medium particles contents $(5-10-20 \mu)$.

Removal of lime from highly saline soil increase the content of fine particles and unexpectedly the course particles also, that is may be attributed to the disappearance of lime as fine particles rather cemented agent. Leaching effectiveness was relatively increased in particles movement associated with lime absence.

2.3- PSD of slightly saline soils: Low soil salinity in the third column led to continues leaching for relatively long time till reaching a stable salinity level of collected periodic leachates. The fine lime particles content were leached and decreased effectively along whole column sections after the experiment even the lower horizon and that may be attributed to that continues leaching. (Fig.1C) After lime removal, the contents of fine and course particles before or after leaching were obviously more than corresponding contents associated with lime, simultaneously with medium particles decreasing. That is could be attributed to carbonate removal as a cemented material or as fine grains, which consider the source of that high lime percentage $(36.7-40 \%)$ in the slightly saline soil.

Consequently, the final soil texture class of each soil column was affected by leaching as showed in table (5). Due to long leaching period, the texture of the last layer of the extremely saline soil column was changed from clay loam to clay. That is attributed to clay content enhancing from $31.43 \%$ to $40.66 \%$ by a ratio of 22.7 $\%$. Clay content of the last layer of the highly saline soil was increased also, but only by a ratio of $7.1 \%$. 
(A)

First column

Extremely

Saline

(B)

Second column Highly Saline

(C)

Third column Slightly Saline

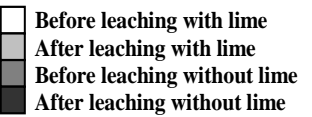

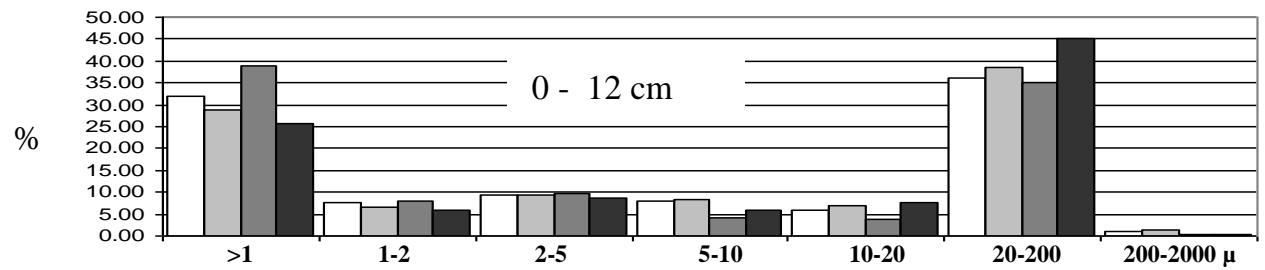
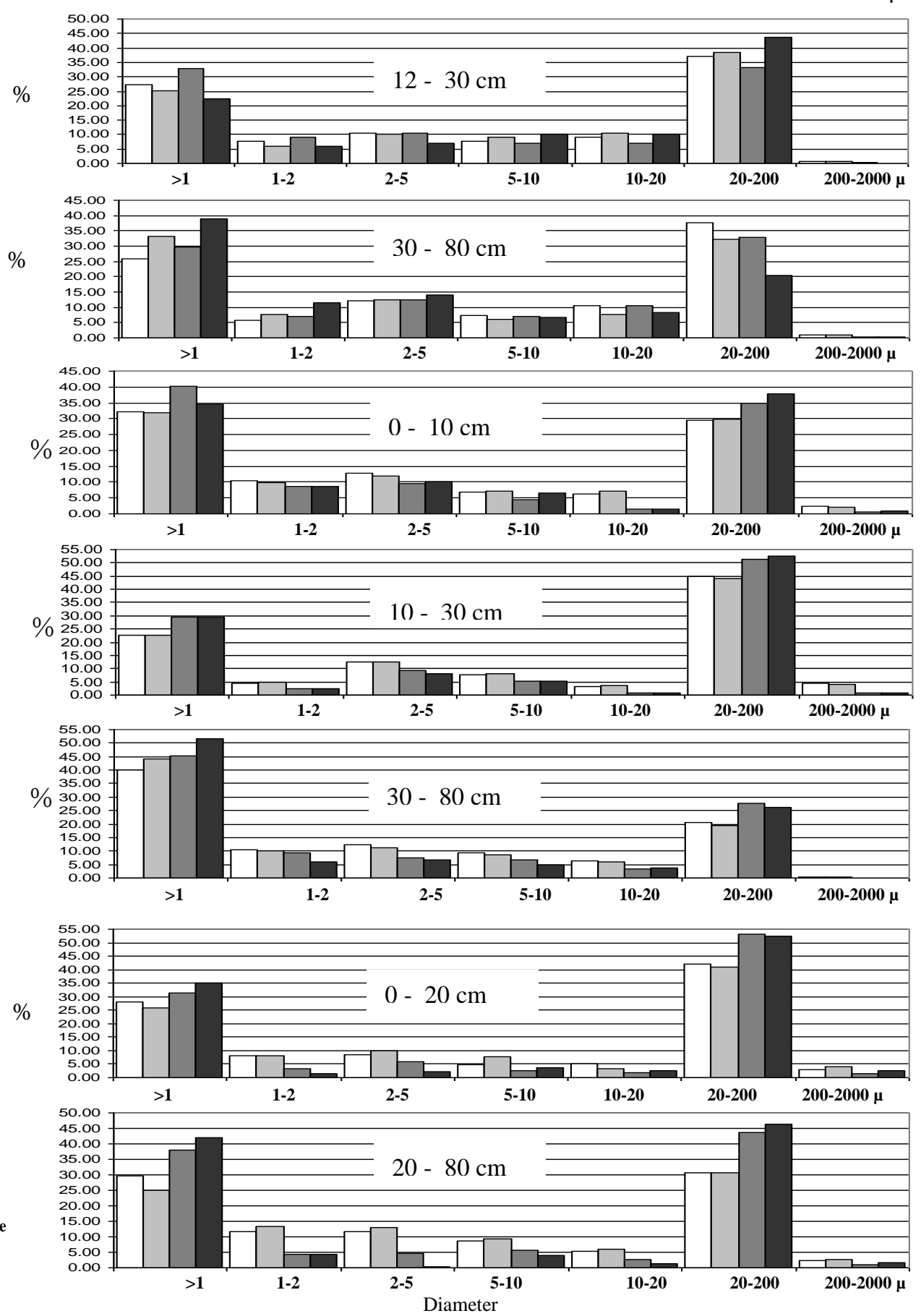

Fig. 1 Particle size distribution histograms for analyzed soil models. 
Table 5. Mechanical analysis of investigated soils at Maryout after the experiment

\begin{tabular}{lcccccccc}
\hline & \multicolumn{3}{c}{ Site 1 } & & \multicolumn{3}{c}{ Site 2 } & \multicolumn{3}{c}{ Site 3 } \\
\hline Horizon depth, cm & $0-12$ & $12-30$ & $30-80$ & $0-10$ & $10-30$ & $30-80$ & $0-20$ & $20-80$ \\
\hline Sand \% & 39.85 & 39.24 & 33.26 & 32.02 & 48.38 & 19.79 & 45.05 & 33.45 \\
\hline Silt \% & 24.72 & 29.63 & 26.08 & 26.29 & 24.43 & 25.94 & 21.23 & $\mathbf{2 8 . 1 7}$ \\
\hline Clay \% & 35.43 & 31.13 & $\mathbf{4 0 . 6 6}$ & 41.69 & 27.19 & $\mathbf{5 4 . 2 7}$ & 33.72 & 38.38 \\
\hline Soil Texture class* & CL & CL & C & C & SCL & C & CL & CL \\
\hline * CL=Clay Loam C=Clay & SCL=Sandy Clay Loam & & & & & &
\end{tabular}

In contrast, texture of the subsurface horizon at the slightly saline column became lighter after leaching as clay loam instead of clay, where silt content was increased versus clay decreasing.

\section{3- Salinity evolution:}

3.1- Salinity downward rate: In general, leaching of extremely saline soil required more time and consumes higher leachates volume and number than those of highly saline soils and both were more than corresponding of slightly saline soil (Tables 1 and 6).It was noticed that the electrical conductivity values of the second drained leachate fractions were reduced significantly by about $77.8 \%, 57.1 \%$ and $15.6 \%$ as shown in table (6) and fig. (3). The experiment was turned off simultaneously with stable salinity level of whole leachates at $0.74,0.44$ and $0.16 \mathrm{dSm}^{-1}$ for extremely, highly and slightly saline soils, respectively. Thus, leaching succeeded in removing about $99.7 \%$, $98.2 \%$ and $93.6 \%$ from the total salt content of the investigated three soil columns, respectively (Fig 2). The high rate of salt decreasing associated with extremely saline column may be attributed to the effect of washing on excess amount of ions under continuous flow or to the relative medium soil texture for whole soil horizons as clay loam if compared with other soil columns which including clay texture class.

3.2- Chemical composition of leachates: It was noticed that $\mathrm{Na}^{+}$represent $54 \%, 48 \%$ and $45 \%$, respectively of the total leachate cations belonging to the investigated soils (Table 6). Results indicated that the concentrations of $\mathrm{Cl}^{-}, \mathrm{Ca}^{++}, \mathrm{Mg}^{++}$then $\mathrm{K}^{+}$followed $\mathrm{Na}^{+}$in descending order in whole drained leachates of the experiment. Data shows that most of the chloride at the extremely saline soil was leached in the first few leachates. Removed cations essentially were in chloride or sulfate forms except for $\mathrm{Ca}^{++}$and $\mathrm{K}^{+}$were present mainly in chloride due the solubility constant of salts which decreased orderly as $\mathrm{CaCl}_{2}-\mathrm{MgCl}_{2}-\mathrm{NaCl}-\mathrm{KCl}-\mathrm{MgSO}_{4}-$ $\mathrm{Na}_{2} \mathrm{SO}_{4}-\mathrm{K}_{2} \mathrm{SO}_{4}-\mathrm{CaSO}_{4}$. Due to the ionic losses during leaching, the concentrations of nutrients have to be carefully monitored for plant growth. Values of sodium adsorption ratio (SAR) were decreased significantly during leaching as showed in table (6). Leaching succeeded in alkalinity removal from both extremely and highly soil columns according to SAR decreasing.

\section{4- Estimation of Calcic horizon formation:}

The different calcareous studied soils showed an increasing rate of $\mathrm{CaCO}_{3}$ deposition due to leaching according to simulation model which assumed a constant dust input equal to $0.5 \mathrm{~g} \mathrm{CaCO}_{3} / \mathrm{m}^{3}$. According to received water quantities, the predicted rates of $\mathrm{CaCO}_{3}$ deposition for the studied soils were 19.9, 16.4 and $09.5 \mathrm{~g} / \mathrm{m}^{3} /$ year, respectively (table 7). Differences between increasing deposition rates of lime within dominant $\mathrm{CaCO}_{3}$ horizons showed in fig. (3), where rates of deposition are curves' slopes. Dominant lime horizons will receive 9950,8200 and $4750 \mathrm{~g} / \mathrm{m}^{3}$ of carbonate, respectively at studied sites after 500 years (fig. 3).

Thus, $0.76,0.64$ and $0.37 \%$ of carbonate will added to receptor horizons after 500 years at the studied sites, respectively which indicate unsuitable conditions for Calcic horizon formation.

\section{CONCLUSION}

- The electrical conductivities of the leachates from whole studied soils were found to decrease sharply among the first few leachates fractions then it slow and steadily decreased. The rate of ionic loss during leaching was found to be orderly as $\mathrm{Na}, \mathrm{Cl}, \mathrm{Ca}, \mathrm{Mg}$, then K. Due to the ionic losses during leaching, the concentrations of fertility elements have to be carefully monitored to sustain healthy plant growth

- Mechanical compositions of soils at the end of experiment indicate that total clay increased with depth for extremely and highly saline columns. These results indicate that some soil aggregates were broken down then clay migrated downward due to water movement. Silt content increased with depth at the slightly saline soil after leaching. Leaching of soil salts with such lime conditions will not resulted in Calcic horizon formation at least over 500 years.

- It is anticipated that similar conditions could prevailed in the field and each situation should be evaluated before water is budgeted for reclamation. It is usually not advisable to leach if the resulting soil will be sodic or alkali, where such soils should receive amendments before being leached. 
Table 6. Salinity levels and associated chemical composition of drained leachates

\begin{tabular}{|c|c|c|c|c|c|c|c|c|c|}
\hline \multirow{2}{*}{ Soil column } & \multirow{2}{*}{$\begin{array}{l}\text { Leachate } \\
\text { fraction }\end{array}$} & \multirow{2}{*}{$\begin{array}{c}\text { Leachate } \\
\text { volume } \\
(\mathrm{ml})\end{array}$} & \multirow{2}{*}{$\begin{array}{l}\text { Leachate } \\
\text { salinity } \\
\mathbf{E C}, \mathbf{d S m}^{-1}\end{array}$} & \multicolumn{5}{|c|}{ Chemical composition meql $^{-1}$} & \multirow{2}{*}{ SAR } \\
\hline & & & & $\mathbf{N a}$ & $\mathbf{K}$ & $\mathbf{C a}$ & Mg & Cl & \\
\hline \multirow{21}{*}{$\begin{array}{l}\text { Extremely } \\
\text { saline soil }\end{array}$} & 1 & 75 & 315.22 & 2079.37 & 34.61 & 882.62 & 472.83 & 1418.49 & 79.87 \\
\hline & 2 & 75 & 55.50 & 471.75 & 12.75 & 155.40 & 83.25 & 124.75 & 43.19 \\
\hline & 3 & 80 & 20.14 & 171.19 & 7.07 & 56.39 & 30.21 & 90.63 & 26.02 \\
\hline & 4 & 75 & 15.25 & 129.63 & 4.63 & 42.70 & 22.88 & 68.63 & 22.64 \\
\hline & 5 & 80 & 10.84 & 92.14 & 3.42 & 30.35 & 16.26 & 48.78 & 19.09 \\
\hline & 6 & 75 & 8.12 & 69.02 & 2.06 & 22.74 & 12.18 & 36.54 & 16.52 \\
\hline & 7 & 75 & 5.21 & 44.29 & 1.90 & 14.59 & 7.82 & 23.45 & 13.23 \\
\hline & 8 & 75 & 3.43 & 29.16 & 1.72 & 9.60 & 5.15 & 15.44 & 10.74 \\
\hline & 9 & 75 & 2.57 & 21.85 & 1.29 & 7.20 & 3.86 & 11.57 & 9.29 \\
\hline & 10 & 82 & 2.24 & 19.04 & 1.12 & 6.27 & 3.36 & 10.08 & 8.68 \\
\hline & 11 & 75 & 1.98 & 16.83 & 0.99 & 5.54 & 2.97 & 8.91 & 8.16 \\
\hline & 12 & 75 & 1.75 & 14.88 & 0.88 & 4.90 & 2.63 & 7.88 & 7.67 \\
\hline & 13 & 85 & 1.50 & 12.75 & 0.75 & 4.20 & 2.25 & 6.75 & 7.10 \\
\hline & 14 & 85 & 1.40 & 11.90 & 0.70 & 3.92 & 2.10 & 6.30 & 6.86 \\
\hline & 15 & 75 & 1.12 & 9.52 & 0.56 & 3.14 & 1.68 & 5.04 & 6.13 \\
\hline & 16 & 80 & 0.94 & 7.99 & 0.47 & 2.63 & 1.41 & 4.23 & 5.62 \\
\hline & 17 & 75 & 0.85 & 7.23 & 0.43 & 2.38 & 1.28 & 3.83 & 5.34 \\
\hline & 18 & 75 & 0.75 & 6.38 & 0.38 & 2.10 & 1.13 & 3.38 & 5.02 \\
\hline & 19 & 80 & 0.74 & 6.29 & 0.37 & 2.07 & 1.11 & 3.33 & 4.99 \\
\hline & 20 & 80 & 0.74 & 6.29 & 0.37 & 2.07 & 1.11 & 3.33 & 4.99 \\
\hline & Total & 1552 & -- & 3227.47 & 225.15 & 1260.81 & 675.44 & 2026.31 & -- \\
\hline \multirow{16}{*}{$\begin{array}{c}\text { Highly saline } \\
\text { soil }\end{array}$} & 1 & 70 & 42.60 & 219.50 & 7.30 & 119.28 & 63.90 & 191.70 & 22.94 \\
\hline & 2 & 75 & 10.72 & 80.40 & 3.36 & 30.02 & 16.08 & 48.24 & 16.75 \\
\hline & 3 & 70 & 8.54 & 64.05 & 2.27 & 23.91 & 12.81 & 38.43 & 14.95 \\
\hline & 4 & 65 & 6.50 & 48.75 & 1.95 & 18.20 & 9.75 & 29.25 & 13.04 \\
\hline & 5 & 65 & 5.10 & 38.25 & 1.55 & 14.28 & 7.65 & 22.95 & 11.55 \\
\hline & 6 & 70 & 4.20 & 31.50 & 1.10 & 11.76 & 6.30 & 18.90 & 10.48 \\
\hline & 7 & 70 & 3.18 & 23.85 & 1.00 & 8.90 & 4.77 & 14.31 & 9.12 \\
\hline & 8 & 70 & 3.00 & 22.50 & 0.96 & 8.40 & 4.50 & 13.50 & 8.86 \\
\hline & 9 & 70 & 2.55 & 19.13 & 0.88 & 7.14 & 3.83 & 11.48 & 8.17 \\
\hline & 10 & 72 & 1.95 & 14.63 & 0.78 & 5.46 & 2.93 & 8.78 & 7.14 \\
\hline & 11 & 72 & 1.14 & 8.55 & 0.57 & 3.19 & 1.71 & 5.13 & 5.46 \\
\hline & 12 & 70 & 0.85 & 6.38 & 0.43 & 2.38 & 1.28 & 3.83 & 4.72 \\
\hline & 13 & 72 & 0.54 & 4.05 & 0.27 & 1.51 & 0.81 & 2.43 & 3.76 \\
\hline & 14 & 72 & 0.44 & 3.30 & 0.22 & 1.23 & 0.66 & 1.98 & 3.39 \\
\hline & 15 & 72 & 0.44 & 3.30 & 0.22 & 1.23 & 0.66 & 1.98 & 3.39 \\
\hline & Total & 1055 & -- & 588.13 & 45.88 & 256.90 & 137.63 & 412.88 & -- \\
\hline \multirow{13}{*}{$\begin{array}{c}\text { Slightly saline } \\
\text { soil }\end{array}$} & 1 & 65 & 4.52 & 22.38 & 2.26 & 12.66 & 6.78 & 20.34 & 7.18 \\
\hline & 2 & 65 & 2.11 & 13.72 & 1.06 & 5.91 & 3.17 & 9.50 & 6.44 \\
\hline & 3 & 60 & 1.84 & 11.96 & 0.92 & 5.15 & 2.76 & 8.28 & 6.01 \\
\hline & 4 & 60 & 1.44 & 9.36 & 0.72 & 4.03 & 2.16 & 6.48 & 5.32 \\
\hline & 5 & 60 & 1.08 & 7.02 & 0.54 & 3.02 & 1.62 & 4.86 & 4.61 \\
\hline & 6 & 60 & 0.85 & 5.53 & 0.43 & 2.38 & 1.28 & 3.83 & 4.09 \\
\hline & 7 & 60 & 0.74 & 4.81 & 0.37 & 2.07 & 1.11 & 3.33 & 3.81 \\
\hline & 8 & 58 & 0.54 & 3.51 & 0.27 & 1.51 & 0.81 & 2.43 & 3.26 \\
\hline & 9 & 62 & 0.38 & 2.47 & 0.19 & 1.06 & 0.57 & 1.71 & 2.73 \\
\hline & 10 & 62 & 0.22 & 1.43 & 0.11 & 0.62 & 0.33 & 0.99 & 2.08 \\
\hline & 11 & 60 & 0.16 & 1.04 & 0.08 & 0.45 & 0.24 & 0.72 & 1.77 \\
\hline & 12 & 60 & 0.16 & 1.04 & 0.08 & 0.45 & 0.24 & 0.72 & 1.77 \\
\hline & Total & 732 & -- & 84.26 & 7.02 & 39.31 & 21.06 & 63.18 & -- \\
\hline
\end{tabular}




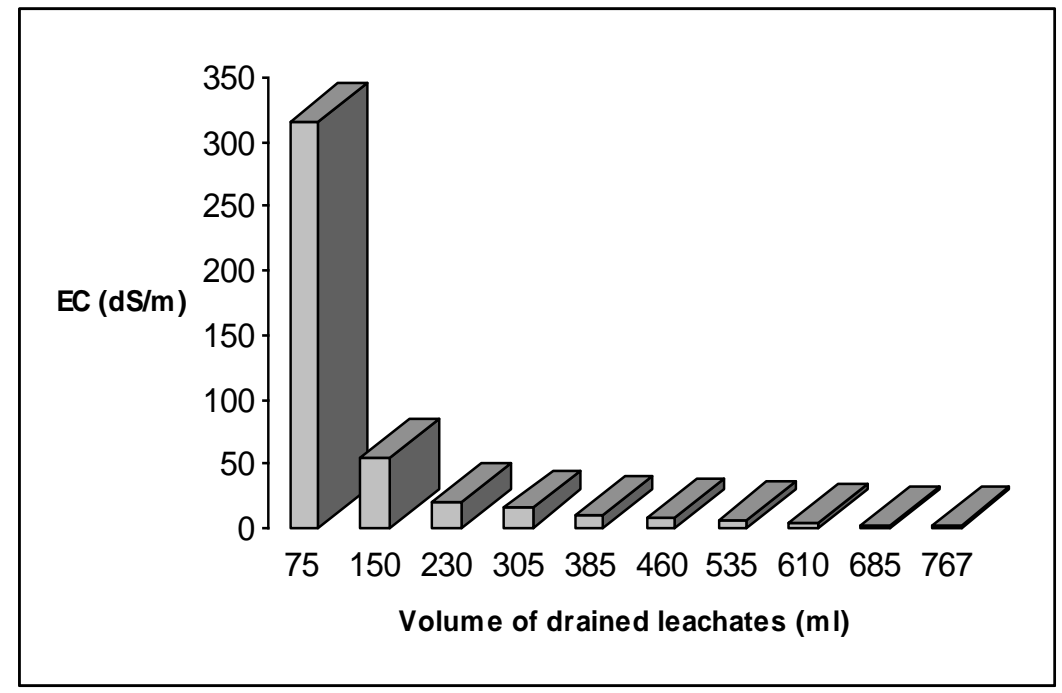

Fig. (2A). Electrical conductivity (EC) of extremely saline soil leachates

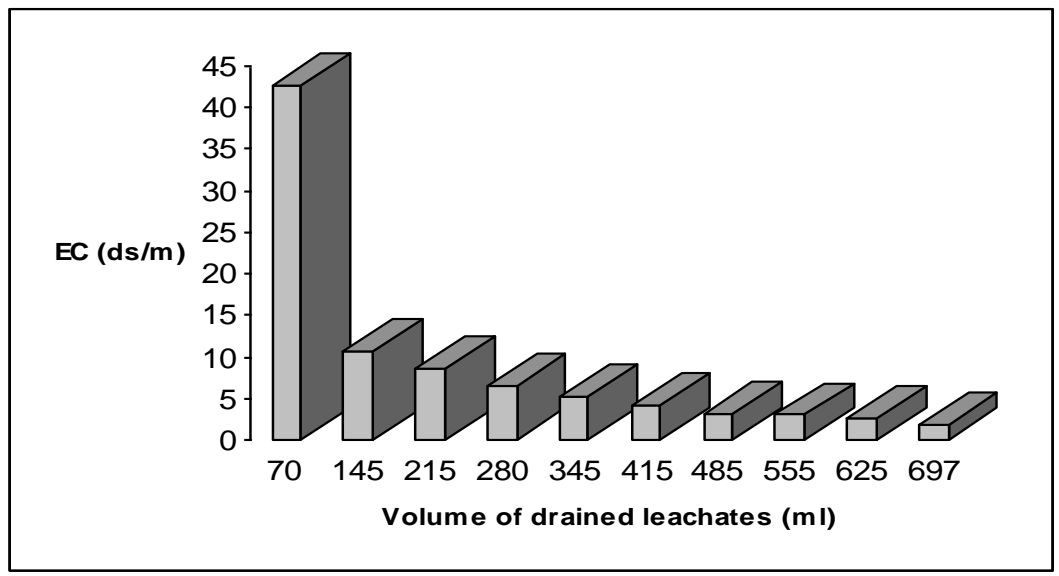

Fig. (2B). Electrical conductivity (EC) of highly saline soil leachates

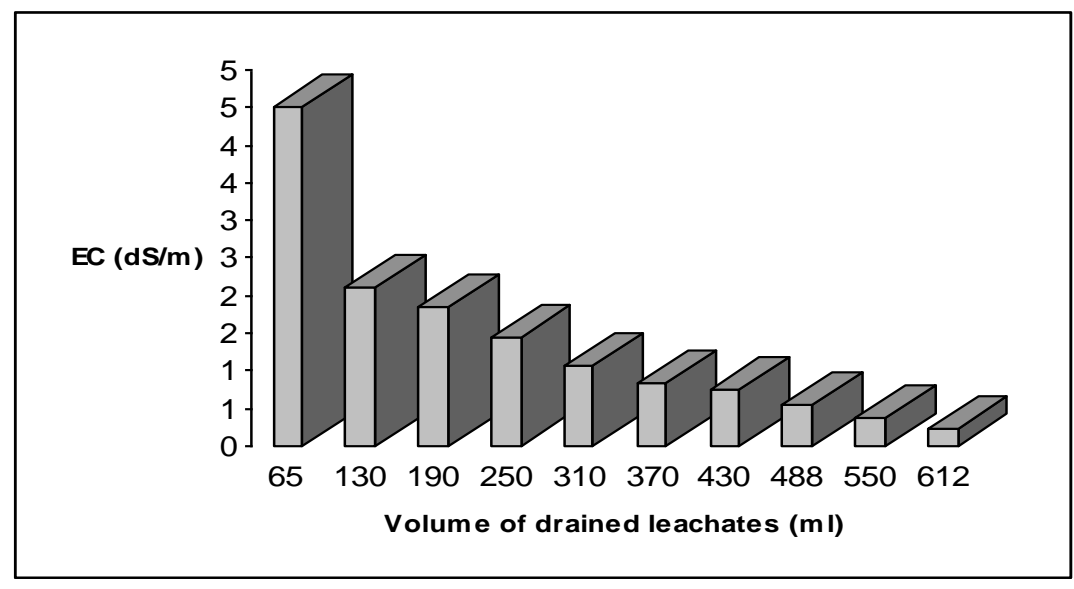

Fig. (2C). Electrical conductivity (EC) of slightly saline soil leachates 
Table 7. Estimated increments in soil carbonate

\begin{tabular}{ccccc}
\hline \multirow{2}{*}{ Site } & \multirow{2}{*}{ Regression Co. $\left(\mathbf{r}^{2}\right)$} & $\begin{array}{c}\text { Initial } \mathrm{CaCO}_{\mathbf{3}} \% \text { at } \\
\text { receptor horizons }\end{array}$ & \multicolumn{2}{c}{ Estimated yearly $\mathrm{CaCO}_{\mathbf{3}}$ incr. } \\
\cline { 4 - 5 } & 0.99 & 26.8 & $\mathbf{g} / \mathbf{m}^{\mathbf{3}}$ & $\mathbf{\%}$ \\
\hline 1 & 1.00 & 32.4 & 19.5 & $1.52 \times 10^{-3}$ \\
\hline 3 & 0.99 & 45.0 & 16.4 & $1.28 \times 10^{-3}$ \\
\hline
\end{tabular}

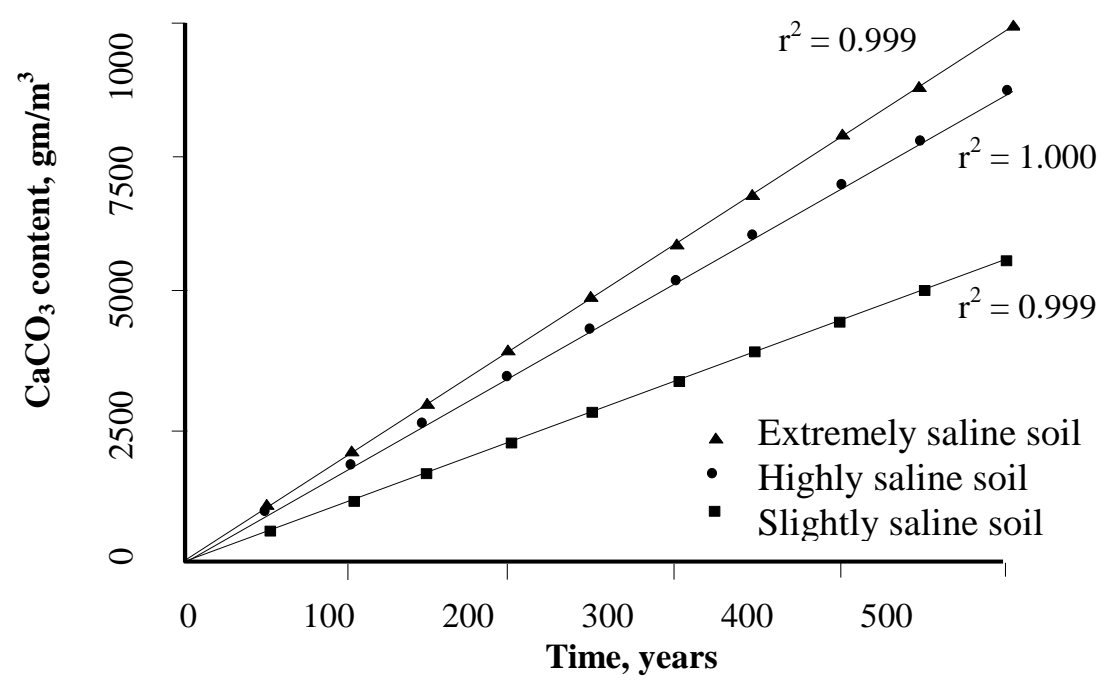

Fig. 3. Rates of $\mathrm{CaCO}_{3}$ deposition in the dominant lime horizons at the invistigation soils

\section{RE FERENCES}

Addiscott, T.M. and A.P. Whitmore. (1991) Simulation of solute leaching in soils of differing permeabilities. Soil Use and Management 7:2, 94-102

Addiscott, T. M. and Wagene, J. (2007) Conceptual Modeling of solute transport. Department of Agronomy, Cornell University, Ithaca, NY 14853, U.S.A.

Andrew J Baird and Simon W Gaffney. (2000) Solute movement in drained fen peat: a field tracer study in a Somerset (UK) wetland. Hydrological Processes 14:14, 2489

Belmans, C., J.G Wesseling and R.A. Feddes (1983). Simulation of the water balance of a cropped soil: SWATRE. Journal of Hydrology, 63, vol. 3/4: 217-286.

Black, C.A., (1965). Methods of soil analysis. Part 2. Argon. Montograph No.9, ASA, Madison, Wisc., USA.

Dam, J.C. van, J.M.H. Hendrickx, M.H. Bannink, (1990) Unsaturated soil water movement in hysteric and water repellent soil. Journl of Hydrology, 120, 359-379.

FAO, (1998). Guidelines for soil profile description. 3rd ed., FAO Publications, Rome.

Feddes, R.A., P.J.Kowalik and Zaradny, (1978). Simulation of field water use and crop yield. Simulation Monographs, Pudoc. Wageningen, The Netherlands.
Feddes, R.A., P. Kabat, P.J.T. van Baked, Bronswijk and J. Halbertsma, (1988). Modelling soil water dynamics in the unsaturated zone - state of the art. Journal of Hydrology, vol 100: 69-111.

Hall, D.G. (1993) An amended functional leaching model applicable to structured soils. I. Model description. European Journal of Soil Science 44:4, 579-588

Hammad, F.A. (1972). Geology of the soils and water resources in the area between Ras El-Hekma and Ras Alam El-Rum. Ph.D Thesis, Fac. Sci., Cairo Univ., Egypt.

James P M Syvitski (editor) (2007). Principles, Methods and Application of Particle Size Analysis. Cambridge University Press. ISBN-13: 9780521044615.

Jarvis, N.J., P.E. Jansson, P. E. Dik and I. Messing (1991) Modelling water and solute transport in macroporous soil. I. Model description and sensitivity analysis. European Journal of Soil Science 42:1, 59-70

L Cai, SA Prathapar and HG Beecher, (2000) Modeling leaching and recharge in a bare transitional red-brown earth ponded with low salinity water in summer, Australian Journal of Experimental Agriculture 34 (7) 1085 - 1092.

Maas, E.V. (1994) Salt tolerance of plants. Handbook of plant science in agriculture, ed. B.R. Christie. Boca Raton, FL: CRC. 
Marion, G.M., Schlesinger, W.H. and Fonteny, P.J. (1985) CALDEP: A regional model for soil $\mathrm{CaCO}_{3}$ deposition. Soil Science, vol: 139, no.: 5. 468-481, USA.

Page, A. L., Miller, R. H. and Keeny, D. R. (1982). Methods of Soil Analysis, Part 2- Chemical and Microbiological Properties. Agronomy Monograph No. 9. ASA, SSSA, Madison, WI.

Poulovassilis, A., Psychoyou, M., and Kerkides, P. (2007) Solute Transport in Soils: An Algorithmic Approach. Water Resources Management,

Rabenhorst, M.C., West, L.T., and Wilding, L.P. (1991) Genesis of Calcic horizon in soils over carbonate rocks. SSSA, special puplication, 26: 61-73.

Richards, R.L., (1954). Diagnosis and improvement of saline and alkali soils. Agriculture Hand Book No. 60, U.S Govt. Printing Office, Washington, USA.

Said, R. (1962). The Geology of Egypt. Elsevier pub. Co., Amsterdam. Semi-arid grassland. Int. J. Remote Sensing, Vol. (14): No. 13, 2535-2546.
Samir, A. M, M.H. Abdel Aziz, M.Y. Afifi, and M.H. ElDosouky (1977) Dynamic process of leaching sandy and alluvial soils. The desert institute bull. (25), 1-2, 161-172.

Scotter, D.R., K. Heng and R.E. White (1991) Two models for the leaching of a non-reactive solute to a mole drain. European Journal of Soil Science 42:4, 565-576

Shata, A. (1971). Geomorphology, pedology and hydrology of the Med. Coast desert of U. A. R. Symposium on the geology of Libya. 431-446. Faculty of Science, Univ. Libya, L. A. R.

Vinten, A.J. and M.H. Redman (1993) Calibration and validation of a model of non-interactive solute leaching in a clay-loam arable soil. Euro. Journal of Soil Science 41:2, 199-214

Zahow M.F. (1988) Simulation model for salt dynamics in calcareous soils. Ph.D. thesis, soil and water dept., Faculty of Agric., Alex. Uni. 


\section{الملخص العربي}

\section{نمذجة تاثير الغسيل على بعض خصائص الأراضى الجيرية المتأثرة بالأملاح بإقليم مريوط، غرب الدلتا}

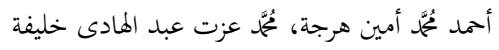

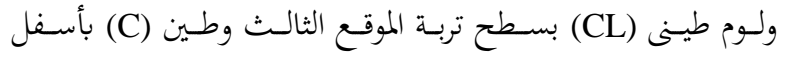

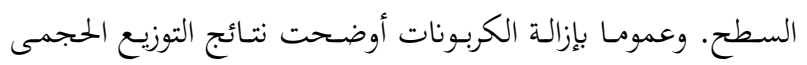

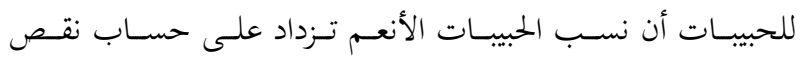

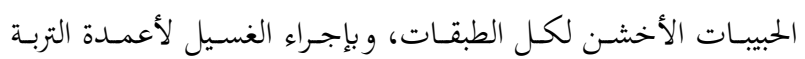

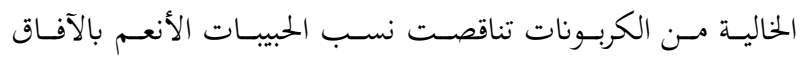

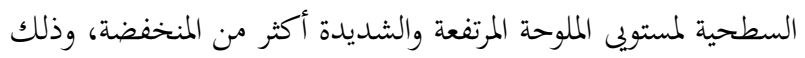

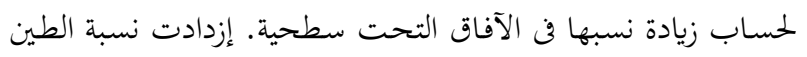

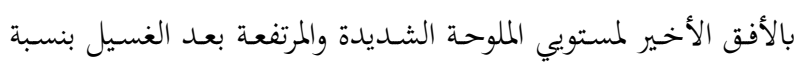

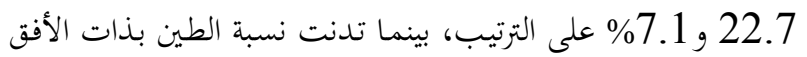
لعامود التربة منخفض الملوحة بعد الغسيل نظرا لإرتفاع نسبة السلت.

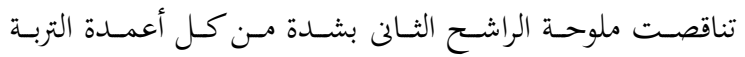

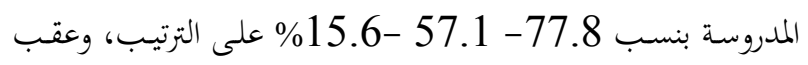
إنتهاء التجربة إتزنت ملوحة الرواشح عند

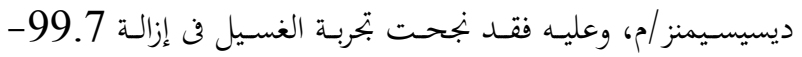
98.2- 93.6 \% مـ أمـلاح أعمدة التربـة الثلاث على الترتيب. أوضحت النتائج أن الفقـــ الأيـونى بالرواشـح كـان بالترتيـب لأمـلاح حيـث كانـت الكـاتيونات إمـا في صـورة كلوريد أو كبريتات. وبمحاكاة ترسيب الكربونات بأعمدة التربة تبين

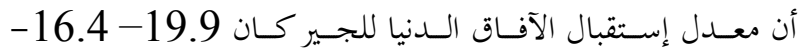

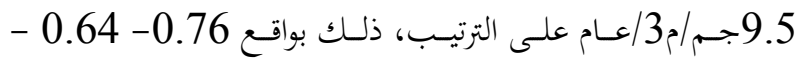

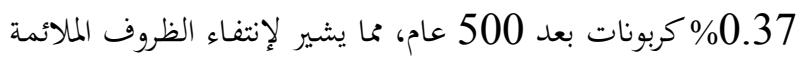
لتكوين الأفق الجيرى التشخيصى خلال هذه الفترة. إعتمدت نتائج التجربة على الفروض النظرية والنتائج المعملية في تقديم نموذج يحاكى ظروف الغسيل الحقلية، على أن يؤخذ في الإعتبار

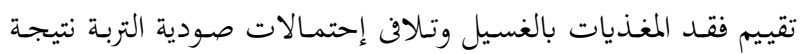
الغسيل بإستخدام المحسنات.
نظرا لأهمية إقليم مريوط وجدوى الإنتفاع بأراضيه الجيرية المستصلحة

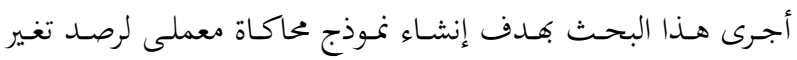
بعض صفات وخصائص الأراضى الجيريـة المتأثرة ملحيـا تحت تأثير أنياء عملية غسيل الأملاح من التربة في محاولة لمحاكاة ديناميكية إستصلاح

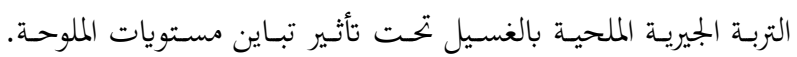
وإختيرت ثناث مواقع بمنطقة الدراسة ممثلة لثلاث مستويات مختلفة--

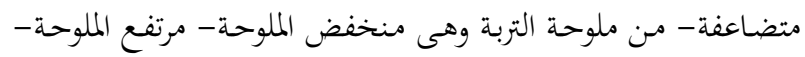

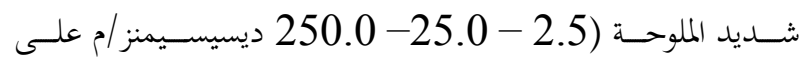
الترتيب)، تم دراستها حقليا بإستخدام ثلاث قطاعات أرضية ممثلة مع داع

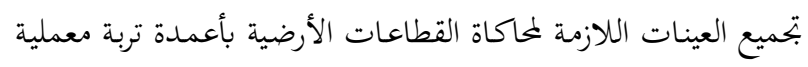
بنفس أعماق آفاق القطاعات حتى عمق 80سم. وقد أجريت بتربة

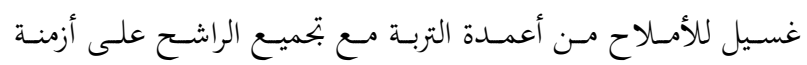

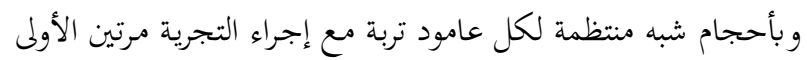

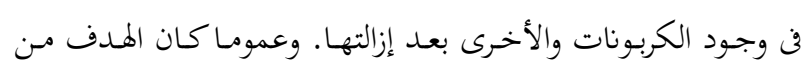
إجراء التجربة دراسة رصد معدل تناقص ملوحة المحاليل الراشحة بتوالى

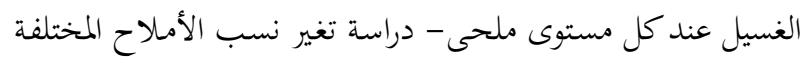

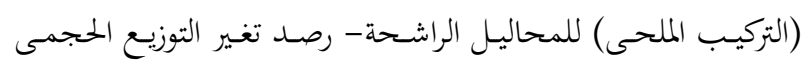

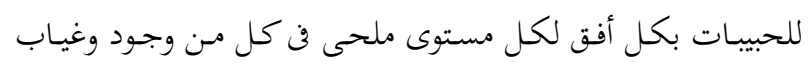

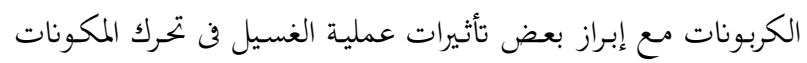
الدقيقة- دراسة إحتمال تكون الأفق الكلسى التشخيصى. وقد أظهرت النتائج أن عدد الرواشح التى إستلزمتها التجربة لتدنية

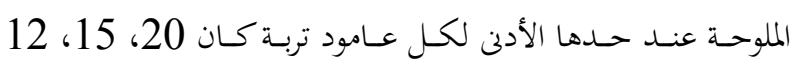

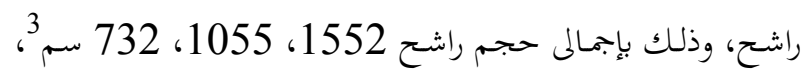
خلال زمن (ق:س) 10:48، 7:41،

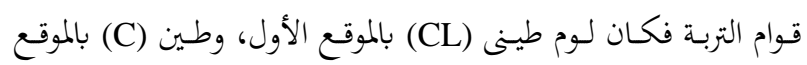

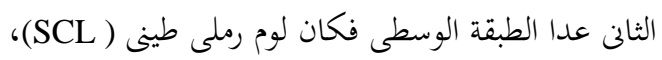

